\title{
First report of tar spot of Toona (Toona ciliata) in India
}

\author{
Sunita Chandel and Vijay Kumar* \\ Department of Plant Pathology, Dr Y S Parmar University of Horticulture and Forestry, Nauni, Solan-173230 \\ (HP), INDIA \\ *Corresponding author. E-mail: vnarwal777@yahoo.com
}

Received: August 10, 2016; Revised received: December 23, 2016; Accepted: April 17, 2017

Abstract: A new foliar disease of toona tree has been reported during continuous surveys conducted at Solan district of Himachal Pradesh during August, 2015 to December, 2015. On the basis of morphological characteristics of the fungus, the fungus was identified as Rhytisma acerinum, which produces symptoms on upper surface of the leaves as numerous small, superficial and blackish lesion which later gives the similar appearance as given by tar. Tar spot of the toona tree produces the ascomata whose size ranges from 14-16 $\mu \mathrm{m}$ with average of $15 \mu \mathrm{m}$, asci length varied from $60-80 \times 9.5-10.2 \mu \mathrm{m}$ and size of ascospores varied from 52-58 x 1.8-2.0 $\mu \mathrm{m}$. Tar Spot disease of leaves of Toona in Himachal Pradesh is the first report of its occurrence and more work is needed so that the disease could remain in manageable level.

Keywords: Ascospores, Rhytisma acerinum, Toona ciliata, Tar spot

\section{INTRODUCTION}

Toona ciliata is a large forest tree in the mahogany family, native to Australia and Asia, but introduced elsewhere as a shade tree and highly valued for its fast-growing aspect and red timber. It is the tree of subtropical climate and can grow in moist localities such as ravines, banks of streams and even swamps. It grows best in fire-protected savannah, abandoned cultivation and in small gaps in forest, and does not do well on dry hill slopes (Weber, 2003; Wagner et al., 1999). T. ciliata is mostly grown for its versatile timber, which is used for building houses and ships, and for high-value goods such as furniture, musical instruments, carvings, and numerous other uses. The flowers yield a reddish dyestuff, while the bark is used to tan leather or to produce string. Traditional medicine makes use of various parts of the plant, chiefly the bark and leaves (Lemmens, 2008). T. ciliata is commonly cultivated as an avenue tree and the leaves are widely used as an animal fodder in India (Edmonds, 1993; Edmonds, 1995) and as an ornamental and wayside tree throughout much of tropical Africa and Asia (Fenton et al., 1977).Several species of insect attack and damage forest trees and young plantations. Similarly in some places, young saplings are attacked and even killed by the parasite Loranthusscurrula. Plantation material is susceptible to decay in fungi such as Ganodermalucidum causing root and butt rot which may be lethal, Phellinus spp., causing white rot of fallen timber or gaining access through wounds exposing dead sapwood, and Trametesstraminea (white stringy rot) usually saprophytic but also act as wound parasite causing trunk rot (Orwa et al., 2009). Other diseases which attack the toona plant are phytoplasma associated diseases such as witches' broom disease (Thakur et al., 2007), showing witches broom symptoms, bacterial diseases of toona caused by Xanthmonas (Zacaroniet al., 2011) and fungi Cercospora leaf spot are common (Silva et al., 2016). In order to identify the diseases of toona in the growing plantation in the Dr. Y. S. Parmar University of Horticulture and Forestry continuous surveys from August, 2015 to December, 2015 were undertaken.

\section{MATERIALS AND METHODS}

The infected leaves of the toona tree were taken and brought to the laboratory for microscopic analysis. Morphological characteristics of the fungus was studied with help of microscope and perithecia, ascus and ascospores size were measured with micrometry as per the methods followed by Hou and Piepenbring, 2005; Wang et al., 2009 and Lantz et al., 2011.

\section{RESULTS AND DISCUSSION}

On upper surface of the leaves numerous small, superficial and blackish distinct tar like spot or lesion were recognised. The leaves exhibit yellow green spots generally in group the lesions continue to grow, and later stages form leaf spots that look like tar (Fig.1. A, B). These spots can grow up to $2-4 \mathrm{~cm}$ in diameter (Lantz et al., 2011). A microscopic sign of the pathogen are the stroma, mats of hyphae found in the lesions. Later these lesions cause senescence of leaves. Ascospores areneedle-shaped or elongated (Fig. 3. E). 


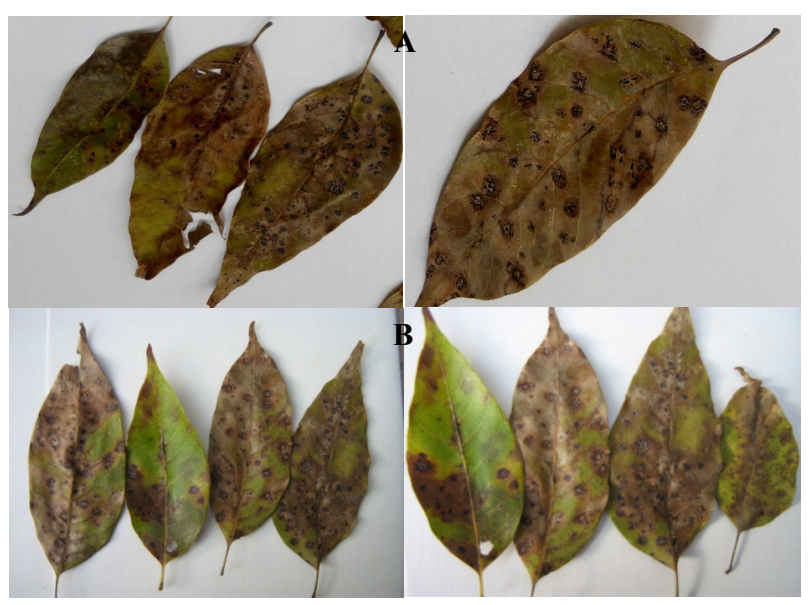

Fig. 1. A and B. Symptoms of tar spot on leaves of Toona ciliate.

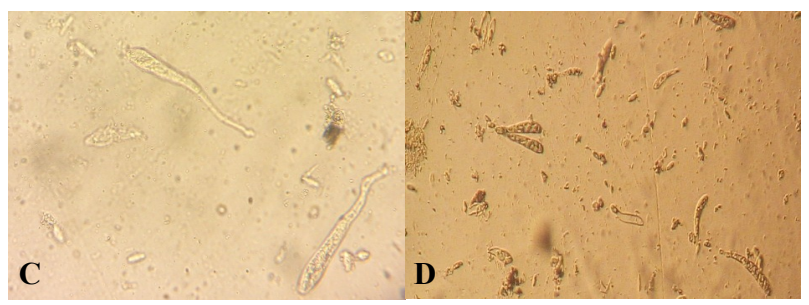

Fig. 2. C. and D. Asci of the Rhytisma acerinum.

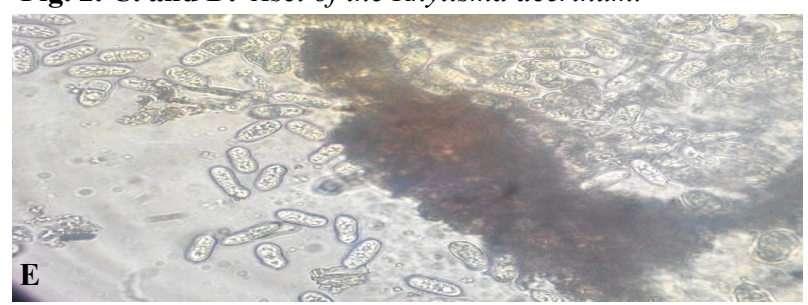

Fig. 3. E. Ascospores of the tar spot (R. acerinumof toona emerging from perithecia.

The tar spot fungus produces the ascomata, asci (Fig.2. C, D) and ascospores whose size ranges from 14-16 $\mu \mathrm{m}$ with average of $15 \mu \mathrm{m}, 60-80 \times 9.5-10.2 \mu \mathrm{m}$ and 52-58x1.8-2.0 $\mu \mathrm{m}$ (Hsiang and Tian, 2007), respectively. On the basis of morphological characteristics of the fungus such as the ascomata, asci and ascospores, pathogen was identified as Rhytisma acerinum. The scanning of literature revealed no record of this pathogen on Toona ciliata in India and elsewhere in world, thus this pathogen appears first time infecting the toona plantation in Solan province of Himachal Pradesh, India.

\section{Conclusion}

The pathogen ( $R$. acerinum) was commonly reported to be infecting the leaves of maple tree. This is the first report when this pathogen was found to be associated leaf spot disease of toona tree. The study would be helpful in identification and in management of the said disease.

\section{REFERENCES}

Edmonds, J. M. (1995). Toona. In: Meliaceae, by Mabberley, D. J., Pannell, C. M., Sing, A, M., eds. Flora Malesiana, Series Spermatophyta, 12(1): 358-371

Edmonds, J. M. (1993). The potential value of Toona species (Meliaceae) as multipurpose and plantation trees in Southeast Asia. Common wealth Forestry Review, 72 (3): 181-186

Fenton, R., Roper, R. E. and Watt, G. R. (1977). Lowland tropical hardwoods: An annotated bibliography of selected species with plantation potential. Wellington, New Zealand: External Aid Division, Ministry of Foreign Affairs.

Hou, C. L. and Piepenbring, M. (2005). Known and two new species of Rhytisma (Rhytismatales, Ascomycota) from China. Mycopathologia, 159, 99-306

Lantz, H., Johnston, P. R., Park, D. and Minter, D. W. (2011). Molecular phylogeny reveals a core clade of Rhytismatales. Mycologia, 103:57-74

Lemmens, R. H. M. J. (2008). Toona ciliata M. Roem. Plant Resources of Tropical Africa, 7(1): 557-559

Orwa, C., Mutua, A., Kindt, R., Jamnadass, R. and Anthony, S. (2009). Agroforestree Database: a tree reference and selection guide version 4.0. World Agroforestry Centre, Kenya

Silva, H. R., Ferreira, M. A., Souza, P. E., Freitas, A. S., Melo, M. P., Costa, S. S. and Pozza E. A. (2016). First Report of Cercospora Leaf Spot Caused by Cercospora cf. alchemillicola in Toona ciliata in Brazil. Plant disease, 10(1):213

Thakur, P. D., Handa A., Sharma, U., Jarial, K. and Bhaik A. (2007). A phytoplasma-associated disease causing degeneration of Toonaciliata - an important agroforestry tree in India. Indian Journal of Agroforestry, 9(1):56-59

Wagner, W. L., Herbst, D. R. and Sohmer, S. H. (1999) Manual of the flowering plants of Hawaii. Revised edition. Honolulu, Hawaii, USA: University of Hawaii Press/Bishop Museum Press, 1919 Pp.

Wang, M. M., Jin, L. T., Jiang, C. X. and Hou, C. L. (2009). Rhytismahuangshanense sp. nov. described from morphological and molecular data. Mycotaxon, 108: 73-82

Weber, E. (2003). Invasive plant species of the world: a reference guide to environmental weeds. Wallingford, UK: CABI Publishing

Zacaroni, A., Souza, R. M., Mansur, T., O., Figueira, A. R., Pozza, E.A. and Sussel, A.A. (2011). First report of a bacterial disease in Australian cedar (Toonaciliata). The American Phytopathological Society

Hsiang, T. and Tian, X. L. (2007). Sporulation and identification of tar spot of maple in Canada. Acta Silv.Lign. Hung., Spec. Edition. 71-74 